\title{
Implementation of Assessment Principles, Performance, and Client Satisfaction of Municipal Assessment Offices in Negros Occidental, Philippines
}

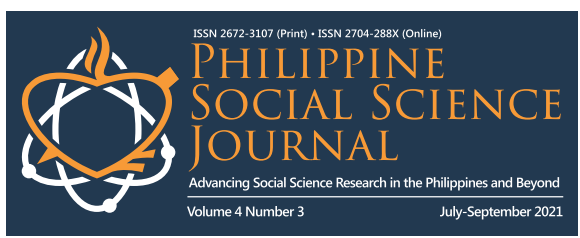

Jennifer S. Tumbagahan¹, Merlita V. Caelian², and Zeaphard Gerhart V. Caelian³

${ }^{1}$ Local Government Unit of San Enrique, Negros Occidental, Philippines

2University of Negros Occidental-Recoletos, Bacolod City, Philippines

${ }^{3}$ Provincial Government of Negros Occidental, Bacolod City, Philippines

\section{Article history: \\ Submitted: 25 July 2021 \\ Revised: 12 August 2021 \\ Accepted: 25 October 2021}

\section{Keywords:}

Public administration

Implementation

Performance

Client satisfaction

Assessment services

Descriptive-comparative

Philippines

ABSTRACT. Accurate implementation of real property assessment principles strengthens real property taxation resulting in improved performance towards client satisfaction. This study assessed the implementation of assessment principles, the performance, and the satisfaction of clients of municipal assessment offices in Negros Occidental, Philippines. It likewise determined the challenges encountered by offices. A descriptive-comparative design was utilized using researcher-made survey instruments administered to assessors and randomly selected staff and clients. Using descriptive and inferential analyses, the findings revealed a very great extent of implementation with no significant differences across all areas when municipalities were grouped as to variables of income classification and land area. While the level of performance was outstanding as a whole, with no significant difference in all areas when grouped as to income class, a significant difference was revealed when assessment offices were grouped as to land area. Clients were very satisfied with assessment services with no significant difference when grouped into income classes. However, there were significant differences in frontline services, service quality, physical setup, and basic facilities. While when grouped as to land area, there was a significant difference across all areas. Several challenges were encountered by assessment offices, such as the agrarian reform program, administrative, policies, and political concerns. The study recommends a review of some policies specifically on the preparation and approval of the schedule of market value.

\subsection{Introduction}

Real property taxes form the biggest part of any local government's resources all over the world (Dimopoulos, 2015). It is levied as an annual tax on the value of the real property, applying assessment principles of appraisal, classification, assessment, and equitability. To implement effective real property assessment, Morissey (2013) recommended a comprehensive and up-to-date database of registered landowners. While the ASEAN member countries are using lower tax rates for economic growth, competition to attract foreign investments through tax exemptions and incentives proved damaging to national revenues (Pinyochatchinda \& Walsh, 2015), hence, the need for local revenues. Generation of revenues from real property taxation demands the performance of government employees of assessment offices in terms of efficiency, quality, and timeliness. However, it was determined that the ASEAN financial crisis was caused by activities in the real estate sector attributed to practices of assessment principles and the performance of appraisers in the property markets (Duca et al., 2010) attributed to challenges encountered by assessment offices in the performance of their functions.

In the Philippines, the 1987 Constitution empowers local government units (LGUs) to manage their financial affairs; thus, property taxation is governed by Republic Act 7160, or the Local Government Code of 1991, which enumerates the taxing powers of the local governments. However, Zaragoza and Caelian (2020) found the dominance of the internal revenue allotment (IRA) in revenues of local government units (LGUs) due to inefficient revenue collection caused by inadequate technical skills on appraisal matters. Gomez (2010) found that with proper valuation standardized across LGUs, the credibility of real estate assessment is established and strengthens the basis of real property taxation. Moreover, to measure effectively the performance of government assessment offices, there

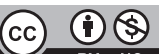

This article published by Philippine Social Science Journal (PSSJ) is licensed under a Creative Commons AttributionNoncommercial 4.0 International (CC BY-NC 4.0). You are free to share (copy and redistribute the material in any medium or format) and adapt (remix, transform, and build upon the material). Under the following terms, you must give appropriate credit, provide a link to the license, and indicate if changes were made. You may do so in any reasonable manner, but not in any way that suggests the licensor endorses you or your use. You may not use the material for commercial purposes. 
is a need to determine clients' satisfaction in several areas such as frontline services, service quality, physical set up, and basic facilities inherent in every government office.

Negros Occidental is also dependent on the Internal Revenue Allotment (IRA), which implies that local revenues are insufficient, the real property tax performance is dismal (Zaragoza \& Caelian, 2020), the percentage share of real property taxes derived from agrarian covered properties to total revenue of the province was only $1.58 \%$ in 2019 , and $80 \%$ of collectibles from property taxes come from agrarian beneficiaries. This implies that assessments of real properties covered by the Agrarian Reform Program were inaccurate, which suggests that the performance of the office of the assessors needs to be examined, hence the conduct of this study.

Studies on property assessment were reviewed, such as of Norregard (2013) and Slack and Bird (2015) on property tax system reforms, Plimmer and McCluskey (2016) on taxation of renters of property, and Goodfellow (2016) on the relationship between property, land, and wealth. In the Philippines, the study of Villaroman (2017) on the factors affecting real property tax collections. Of the studies reviewed, no study focused on implementing assessment principles, the performance of assessment offices, the satisfaction of clients, and challenges encountered by assessment offices, hence a gap in the literature.

This study determined the extent of implementation of assessment principles in the appraisal, classification, assessment, and equitability. Likewise, it assessed the performance of the assessment offices in terms of efficiency, quality, and timeliness. It also investigated the challenges encountered by the assessment offices and clients' satisfaction in the areas of frontline services, service quality, physical setup, and basic facilities. The findings were utilized as the basis of a strategic plan to enhance real property assessment principles implementation, level of performance of offices, and client satisfaction.

\subsection{Framework of the Study}

The paper theorized that accurate implementation of assessment principles results in an outstanding performance of assessment offices that will contribute to clients' satisfaction. The study provided evidence that the trust that clients have in property assessment is attributed to certainty and reliability of the activities and procedures in the valuation of properties by ensuring the consistency, uniformity, and accuracy of valuations and the accurate application of the rules and regulations on principles of property assessment (Gayer \& Mourre, 2012).

The study is anchored on the theory of New Public Management (NPM) advocated by Oxborne and Gaebler (1992), the core principle of which is client orientation with emphasis on improving the quality of services implemented, on setting standards of quality, and responding to clients' satisfaction. The objective of NPM is to transform the public sector through organizational reforms that focus on implementation (Stoker, 2018). The application of this theory to the implementation of assessment principles is demonstrated in the accurate application of the principles of appraisal, classification, assessment, and equitability.

Further, the study anchored on the Total Quality Management Theory of Lu (2001), which is a collective, interlinked system of quality management practices associated with organizational performance (Kuei \& Madu, 1995), which is an approach to the way operations and processes should be managed by measuring the performance of the assessment offices in terms of efficiency, quality, and timeliness. Likewise, the dimensions of the SERVQUAL model (tangibility, reliability, assurance, responsiveness, and empathy) were used as a guide to determine the satisfaction of clients specifically on service quality in the areas of frontline services, physical setup, and basic facilities that determined the gaps in management practices (Soutar, 2001).

These theories are relevant in this study because the findings generated baseline information for the proposed strategic plan to enhance the implementation, improve the performance, and sustain the clients' level of satisfaction towards assessment services.

\subsection{Methods}

The study used a descriptive-comparative research design. A descriptive design was utilized to describe the extent of implementation of assessment principles, level of performance of assessment offices, and satisfaction of clients on services of the assessment offices. The descriptive design is appropriate because the researcher observed a large mass of the target population and made the required conclusion about the variables (Ritchie et al., 2013). 
The study also utilized the comparative design to determine the differences in the extent of implementation of assessment principles, the performance of assessors, and the level of satisfaction of clients when municipalities were grouped into income classification and land area. The comparative design is appropriate because it allows the researcher to examine the differences and similarities between the variables (Kumar, 2014).

A researcher-made survey questionnaire based on the provisions of RA 7160 was designed and used to measure the extent of implementation of assessment principles. The survey instrument consists of three parts: Part 1 is on the profile of the respondent municipality, Part II is the questionnaire proper to measure the extent of implementation of assessment principles, and Part III is a checklist that enumerates the challenges encountered by assessment offices. The said instrument was administered to the assessors and their staff, measured on a scale of 1 to 5 ; the highest is 5 , which is very great, and the lowest is 1 , which is very poor.

Meanwhile, the level of performance of assessment offices was gauged with secondary data using the Office Performance Commitment Review (OPCR) of the Civil Service Commission. The level of performance was also measured on a scale of 1 to 5 , with 5 being the highest interpreted outstanding and 1 , the lowest interpreted very poor.

Likewise, the survey instrument on the level of satisfaction of the clients was based on the Civil Service Commission (CSC) Report Card Survey aligned with the SERVQUAL model. It consists of two parts: Part 1 is the profile of the municipality, and Part II contains questions to measure the level of satisfaction of clients in the areas of frontline services, service quality, physical setup, and basic facilities. It is also measured on a scale of 1 to 5 , with 5 as the highest interpreted as very satisfied and 1 as the lowest interpreted as very unsatisfied.

The survey instruments were subjected to validity and reliability tests. The validity test was conducted among the city assessors using the criteria of Good and Scates. The validity scores were 4.82 for the extent of implementation and 4.78 for the level of satisfaction, denoting that the instruments were valid. The instruments were likewise subjected to reliability tests to ensure that the items included measure what the instruments purport to measure by administering to 30 personnel of the assessor's offices and 30 clients who were not respondents of the study using the Cronbach's Alpha test. The reliability scores for the extent of implementation were 0.933 and 0.935 for the level of satisfaction, which means that both questionnaires have strong internal reliability.

The descriptive and comparative analyses were used to present and examine the differences among variables. To answer the problem that examined the extent of implementation of assessment principles, level of performance and client satisfaction, mean and standard deviation were used. The normality test using the Kolmogorov-Smirnov test revealed that the variables appraisal, classification, assessment, and equitability, and variables on performance and satisfaction were all not normally distributed; hence, non-parametric statistical tools were used for comparative analysis. Kruskal Wallis and Mann-Whitney $U$ tests were used to determine the differences in the extent of implementation, level of performance, and client satisfaction in terms of income classification and land area, respectively. On the challenges encountered in implementation, the frequency count and percentage distribution were used.

\subsection{Results and Discussion}

\section{Extent of implementation of assessment principles}

As a whole, the implementation of assessment principles is to a very great extent $(M=4.66$; $S D=0.33$ ). The standard deviation indicates how far the responses deviate from the mean. Equitability was rated to the highest very great extent $(M=4.74 ; S D=0.34)$ while appraisal was rated lower $(M=4.41 ; S D=0.47)$, also very great extent where the deviation is greater than that on equitability.

This finding indicates that assessment personnel follows the prescribed guidelines on assessment as mandated in the Local Government Code of 1991 and the prescribed manual by the Bureau of Local Government Finance (BLGF) of the Department of Finance (DOF). This finding strengthened the studies of Gayer and Mourre (2012) and Goodfellow (2016) that applying the procedures in the valuation of real properties means ensuring the consistency, uniformity, and accuracy of valuations and applying the rules and regulations and principles of property assessment as provided by law indicates great implementation. It is substantiated by the findings of Felis (2014) and Zaragoza and Caelian (2020) that property taxation determines the revenue potential of local governments and constitutes a stable part of their own resources. 
In terms of the variables, equitability was rated to a very great extent; it suggests that there is a proportionate valuation of properties, market value is reasonable and logical, and taxes are determined by wealth rather than percentage levy (Monkam \& Moore, 2015).

While the lower mean rating on implementation of assessment principles was on appraisal, they are still interpreted to a very great extent. It implies that the basis of the determination of market value is outdated because the preparation used the sales comparison approach with sales taken three or more years prior to its application (Tumbagahan, 2018).

This finding of the lowest rating on the assessment principle, appraisal, conforms to the study of Kucharska-Stasiak (2013) that a valuation is only an estimate, the outcome of which depends on assumptions. Also, Effiong (2015) states that variance in valuation is inevitable because the opinion of value could enter the process at any point of the assessment process. Villaroman (2017) substantiated the finding that involved government agencies do not extend enough technical assistance on appraisal matters to address the needed expertise and skills; hence, the collections of real property taxes are affected.

Table 1A. Extent of Implementation of Assessment Principles

\begin{tabular}{lllllllllll}
\hline \multirow{2}{*}{ Variables } & \multicolumn{3}{l}{ Appraisal } & \multicolumn{4}{c}{ Classification } & \multicolumn{4}{c}{ Assessment } \\
\cline { 2 - 10 } & $\mathrm{M}$ & $\mathrm{SD}$ & Int & $\mathrm{M}$ & $\mathrm{SD}$ & Int & $\mathrm{M}$ & $\mathrm{SD}$ & Int \\
\hline Land Area & & & & & & & & & \\
$\quad$ Smaller & 4.66 & 0.44 & VGE & 4.71 & 0.35 & VGE & 4.73 & 0.36 & VGE \\
$\quad$ Bigger & 4.57 & 0.49 & VGE & 4.62 & 0.40 & VGE & 4.62 & 0.40 & VGE \\
Income Class & & & & & & & & & \\
$\quad$ First & 4.55 & 0.52 & VGE & 4.66 & 0.37 & VGE & 4.61 & 0.41 & VGE \\
Second & 4.71 & 0.45 & VGE & 4.65 & 0.43 & VGE & 4.69 & 0.44 & VGE \\
Third & 4.36 & 0.43 & VGE & 4.58 & 0.33 & VGE & 4.54 & 0.31 & VGE \\
$\quad$ Fourth & 4.80 & 0.22 & VGE & 4.70 & 0.41 & VGE & 4.87 & 0.17 & VGE \\
As a Whole & 4.61 & 0.47 & VGE & 4.65 & 0.38 & VGE & 4.66 & 0.39 & VGE \\
\hline Note: VGE=Very Great Extent & & & & & & & &
\end{tabular}

Table 1B. Extent of Implementation of Assessment Principles

\begin{tabular}{lllllll}
\hline \multirow{2}{*}{ Variables } & \multicolumn{5}{c}{ Equitability } & \multicolumn{4}{c}{ Implementation } \\
\cline { 2 - 7 } & $\mathrm{M}$ & $\mathrm{SD}$ & $\mathrm{Int}$ & $\mathrm{M}$ & $\mathrm{SD}$ & Int \\
\hline Land Area & & & & & & \\
$\quad$ Smaller & 4.81 & 0.32 & VGE & 4.72 & 0.33 & VGE \\
$\quad$ Bigger & 4.69 & 0.36 & VGE & 4.63 & 0.32 & VGE \\
Income Class & & & & & & \\
$\quad$ First & 4.70 & 0.39 & VGE & 4.63 & 0.35 & VGE \\
$\quad$ Second & 4.83 & 0.30 & VGE & 4.72 & 0.35 & VGE \\
$\quad$ Third & 4.68 & 0.32 & VGE & 4.54 & 0.31 & VGE \\
$\quad$ Fourth & 4.77 & 0.26 & VGE & 4.79 & 0.19 & VGE \\
As a Whole & 4.74 & 0.34 & VGE & 4.66 & 0.33 & VGE \\
\hline
\end{tabular}

Note: VGE=Very Great Extent

\section{Level of performance of assessment offices}

The level of performance of assessment offices as a whole is outstanding $(M=4.50: S D=0.31)$, with efficiency rated the highest $(M=4.60: S D=0.36)$ interpreted as outstanding. The lower rating is on timeliness $(M=4.33: S D=0.41)$, still interpreted as outstanding, which also exceeded the standard performance. The deviation from the mean is smaller on efficiency than on timeliness which means that the appreciation of the respondents is more or less the same on efficiency rather than on timeliness.

This outstanding performance is demonstrated by assessors awarded by the Regional Office of BLGF DOF and some assessors designated by municipal mayors to handle functions such as Human Resource Officers, acting budget officers, and chairpersons of the Bids and Awards Committee, which shows the trust of the local chief executives in the abilities of the assessors. 
This finding strengthens the studies of Khalfan et al. (2020), Sadikoglu and Olcay (2014), and Benedicto and Caelian (2021) that performance involves practices that improve efficiency, competitiveness, and quality service, which are above standards. That performance is affected by the habit of work, experience, and competence (Roberto \& Madrigal, 2018), like seeking further studies and pursuing a master's degree and other professional courses to maintain performance quality. Kadiresan et al. (2015) and Laguyo and Caelian (2020) stated that training and continuing education impact employees' performance.

In terms of the variables, the highest is on efficiency, with all municipalities rated outstanding. This finding is attributed to the prompt and courteous response to requests, judicious use of supplies and equipment, providing forms to clients for free, following the ethical standards of conduct, and the provisions of the Anti-Red Tape Act as prescribed by the Civil Service Commission for government employees (Alegata \& Caelian, 2019; Benedicto \& Caelian, 2021). The result is aligned with Cheymetova and Sherbakov (2017) and Inuwa (2016) on using indicators to measure efficiency that employee performance is influenced by organizational commitment affecting efficiency and performance.

Meanwhile, the lowest mean rating was on timeliness $(M=4.33)$, although still interpreted as outstanding. The lower mean rating on timeliness in submitting outputs to the provincial office, including the OPCR, is attributed to the current pandemic. Health protocols hinder the inspection of properties to avoid contamination and the spread of the disease. It must be noted that all assessment offices were rated outstanding except second-class municipalities that were rated very satisfactory on timeliness. A cursory investigation found that in second class municipalities, one assessor was on maternity leave, the other municipality had a newly appointed assessor, and a clerk only manned the third-class municipality, the position being vacant explains the lower mean rating on the timeliness of submission of outputs and a lower mean rating on quality $(M=4.09)$ interpreted as very satisfactory (Reyes, 2013). Singh (2016) found that government employees practice service quality with timeliness as an essential component correlated with job performance; however, they have become complacent (Benedicto \& Caelian, 2021).

Table 2A. Level of Performance of Assessment Offices

\begin{tabular}{|c|c|c|c|c|c|c|}
\hline \multirow{2}{*}{ Variable } & \multicolumn{3}{|c|}{ Quality } & \multicolumn{3}{|c|}{ Efficiency } \\
\hline & M & SD & Int & M & SD & Int \\
\hline \multicolumn{7}{|l|}{ Land Area } \\
\hline Smaller & 4.55 & 0.38 & Os & 4.59 & 0.39 & Os \\
\hline Bigger & 4.50 & 0.46 & Os & 4.61 & 0.36 & Os \\
\hline \multicolumn{7}{|c|}{ Income Class } \\
\hline First & 4.59 & 0.65 & Os & 4.68 & 0.49 & Os \\
\hline Second & 4.66 & 0.18 & Os & 4.53 & 0.35 & Os \\
\hline Third & 4.09 & 0.04 & VS & 4.56 & 0.62 & Os \\
\hline Fourth & 4.59 & 0.06 & Os & 4.60 & 0.06 & Os \\
\hline As a Whole & 4.52 & 0.40 & Os & 4.60 & 0.36 & Os \\
\hline
\end{tabular}

Note: Os=Outstanding, VS=Very Satisfactory

Table 2B. Level of Performance of Assessment Offices

\begin{tabular}{lllllll}
\hline \multirow{2}{*}{ Variable } & \multicolumn{3}{c}{ Timeliness } & \multicolumn{4}{c}{ Performance } \\
\cline { 2 - 7 } & $\mathrm{M}$ & $\mathrm{SD}$ & Int & $\mathrm{M}$ & $\mathrm{SD}$ & Int \\
\hline Land Area & & & & & & \\
$\quad$ Smaller & 4.34 & 0.43 & Os & 4.52 & 0.29 & Os \\
$\quad$ Bigger & 4.33 & 0.43 & Os & 4.48 & 0.36 & Os \\
Income Class & & & & & & \\
$\quad$ First & 4.48 & 0.43 & Os & 4.57 & 0.50 & Os \\
$\quad$ Second & 3.85 & 0.18 & VS & 4.39 & 0.15 & Os \\
$\quad$ Third & 4.37 & 0.27 & Os & 4.35 & 0.30 & Os \\
$\quad$ Fourth & 4.60 & 0.25 & Os & 4.61 & 0.12 & Os \\
As a Whole & 4.33 & 0.41 & Os & 4.50 & 0.31 & Os \\
\hline S
\end{tabular}

Note: Os=Outstanding, VS=Very Satisfactory 


\section{Level of satisfaction of clients}

As a whole, clients are very satisfied $(M=4.47: S D=0.43)$ in the delivery of assessment services, which exceeds expectations, but the deviation from the mean indicates that some clients have issues with the delivery of assessment services. Clients are satisfied with assessment services because no complaint was filed against any of the offices of the municipalities, nor was there a case filed against any of the assessors. As confirmed in studies of Pukite and Geipele (2017) and Yang et al. (2019), client satisfaction is revealed in their participation in a public forum because it is not simply a matter of meeting expressed needs but finding out unexpressed needs, setting priorities, allocating resources, and publicly justifying and accounting for what has been done.

In terms of the variables, frontline services were rated $(M=4.59)$, the highest interpreted as very satisfied. This indicates that the assessment offices provide accurate and responsive services, employees demonstrate knowledge and expertise, are courteous and helpful, are willing to help property owners, and provide services to property owners on time. This also demonstrates that employees adhere to the mandate of the Civil Service Commissions' Citizens' Charter, where clients are guided on the activities, processes, procedures, and fees to avail of the service as well as a provision on how to file their complaints (Benedicto \& Caelian, 2021; Alegata \& Caelian, 2019).

The highest mean rating on frontline services confirmed the findings of Perez and Ilagan (2020), Lee et al. (2016), and Chaoluck (2016) that client satisfaction depends highly on the behaviors of frontline service providers.

Meanwhile, the lower mean rating $(M=4.39)$ on the level of satisfaction was on the variable service quality, still interpreted as very satisfied. All activities on service quality are mandates of RA 9485, otherwise known as the Anti-Red Tape Act, and provided under the citizens' charter (Alegata \& Caelian, 2019). The lower mean rating is attributed to simplifying forms so they are easy to understand which cannot be done by the assessors' office because higher offices prescribe them. Furthermore, the lower mean rating contributed to the absence of regular consultation with the clients considering the current pandemic. Clients who were respondents of this study have availed of

Table 3A. Level of Satisfaction of Clients

\begin{tabular}{lllllllllll}
\hline \multirow{2}{*}{ Variables } & \multicolumn{3}{l}{ Frontline Services } & \multicolumn{3}{c}{ Service Quality } & \multicolumn{3}{c}{ Physical Setup } \\
\cline { 2 - 10 } & $\mathrm{M}$ & SD & Int & $\mathrm{M}$ & SD & Int & $\mathrm{M}$ & SD & Int \\
\hline Land Area & & & & & & & & & \\
$\quad$ Smaller & 4.68 & 0.50 & VS & 4.51 & 0.62 & VS & 4.57 & 0.57 & VS \\
$\quad$ Bigger & 4.52 & 0.45 & VS & 4.29 & 0.41 & VS & 4.40 & 0.42 & VS \\
Income Class & & & & & & & & & \\
$\quad$ First & 4.58 & 0.42 & VS & 4.32 & 0.45 & VS & 4.44 & 0.44 & VS \\
$\quad$ Second & 4.52 & 0.51 & VS & 4.37 & 0.52 & VS & 4.51 & 0.49 & VS \\
$\quad$ Third & 4.66 & 0.67 & VS & 4.46 & 0.77 & VS & 4.49 & 0.73 & VS \\
$\quad$ Fourth & 4.67 & 0.39 & VS & 4.63 & 0.45 & VS & 4.56 & 0.46 & VS \\
As a Whole & 4.59 & 0.48 & VS & 4.39 & 0.53 & VS & 4.48 & 0.50 & VS \\
\hline
\end{tabular}

Note: VS=Very Satisfied

Table 3B. Level of Satisfaction of Clients

\begin{tabular}{lllllll}
\hline \multirow{2}{*}{ Variables } & \multicolumn{4}{l}{ Basic Facilities } & \multicolumn{3}{l}{ Satisfaction } \\
\cline { 2 - 7 } & $\mathrm{M}$ & $\mathrm{SD}$ & Int & $\mathrm{M}$ & $\mathrm{SD}$ & Int \\
\hline Land Area & & & & & & \\
$\quad$ Smaller & 4.54 & 0.60 & VS & 4.58 & 0.52 & VS \\
$\quad$ Bigger & 4.32 & 0.45 & VS & 4.39 & 0.32 & VS \\
Income Class & & & & & & \\
$\quad$ First & 4.34 & 0.47 & VS & 4.42 & 0.35 & VS \\
$\quad$ Second & 4.44 & 0.53 & VS & 4.47 & 0.44 & VS \\
$\quad$ Third & 4.54 & 0.68 & VS & 4.54 & 0.69 & VS \\
$\quad$ Fourth & 4.54 & 0.56 & VS & 4.60 & 0.39 & VS \\
As a Whole & 4.41 & 0.53 & VS & 4.47 & 0.43 & VS \\
\hline
\end{tabular}

Note: VS=Very Satisfied 
the services of the assessment offices at the time of the data gathering. Therefore, their very satisfied ratings of the quality of the service are truthful.

This finding strengthened the studies of Khan and Fasih (2014) and Ariani (2015). They found that service quality has a significant and positive association with customer satisfaction. The studies of Pakurar et al. (2019) using the Servqual Model to measure service quality and Mustafa and Okeyo (2018) stated that a quality customer service delivery is displayed by employees who are attuned to the goals and objectives of the organization.

\section{Difference in the extent of implementation according to land area}

There is no significant difference in the extent of implementation of assessment principles in the areas of appraisal, classification, assessment, and equitability when municipalities are grouped according to the land area.

This finding implies that regardless of whether the municipality is with bigger or smaller land areas, the application of the assessment principles and tax collection is the same (Zaragoza \& Caelian, 2020) because they are guided by the provisions of the Local Government Code. Further, all assessors follow the same ordinance enacted by the Provincial Government in their assessment activities (Plimmer \& McCluskey, 2016).

Table 4. Difference in the Extent of Implementation of Assessment Principles according to Land Area

\begin{tabular}{|c|c|c|c|c|c|}
\hline \multirow{2}{*}{ Variable } & \multicolumn{2}{|c|}{ Land Area } & \multirow{2}{*}{$U$} & \multirow{2}{*}{ Z } & \multirow{2}{*}{$p$} \\
\hline & Smaller & Bigger & & & \\
\hline Appraisal & $\begin{array}{l}4.66 \\
(0.44)\end{array}$ & $\begin{array}{l}4.57 \\
(0.49)\end{array}$ & 812.000 & -0.883 & 0.377 \\
\hline Classification & $\begin{array}{l}4.71 \\
(0.35) \\
\end{array}$ & $\begin{array}{l}4.62 \\
(0.40) \\
\end{array}$ & 792.500 & -1.053 & 0.292 \\
\hline Assessment & $\begin{array}{l}4.73 \\
(0.36)\end{array}$ & $\begin{array}{l}4.62 \\
(0.40)\end{array}$ & 775.000 & -1.229 & 0.219 \\
\hline Equitability & $\begin{array}{l}4.81 \\
(0.32)\end{array}$ & $\begin{array}{l}4.69 \\
(0.36) \\
\end{array}$ & 747.500 & -1.536 & 0.124 \\
\hline Implementation & $\begin{array}{l}4.72 \\
(0.33)\end{array}$ & $\begin{array}{l}4.63 \\
(0.32)\end{array}$ & 736.500 & -1.521 & 0.128 \\
\hline
\end{tabular}

Note: the difference is significant when $\mathrm{p} \leq 0.05$

\section{Difference in the extent of implementation in terms of income classification}

There is no significant difference in the extent of implementation of assessment principles when LGUs are grouped according to income class. Assessors are guided by the same guidelines

Table 5. Difference in the Extent of Implementation of Assessment Principles according to Income Class

\begin{tabular}{|c|c|c|c|c|c|c|c|}
\hline \multirow{2}{*}{ Variable } & \multicolumn{4}{|c|}{ Income Class } & \multirow{2}{*}{$x^{2}$} & \multirow{2}{*}{$d f$} & \multirow[b]{2}{*}{$\mathrm{p}$} \\
\hline & First & Second & Third & Fourth & & & \\
\hline Appraisal & $\begin{array}{l}4.55 \\
(0.52)\end{array}$ & $\begin{array}{l}4.71 \\
(0.45)\end{array}$ & $\begin{array}{l}4.36 \\
(0.43)\end{array}$ & $\begin{array}{l}4.80 \\
(0.22)\end{array}$ & 6.898 & 3 & 0.075 \\
\hline Classification & $\begin{array}{l}4.66 \\
(0.37) \\
\end{array}$ & $\begin{array}{l}4.65 \\
(0.43) \\
\end{array}$ & $\begin{array}{l}4.58 \\
(0.33) \\
\end{array}$ & $\begin{array}{l}4.70 \\
(0.41) \\
\end{array}$ & 1.428 & 3 & 0.699 \\
\hline Assessment & $\begin{array}{l}4.61 \\
(0.41)\end{array}$ & $\begin{array}{l}4.69 \\
(0.44)\end{array}$ & $\begin{array}{l}4.54 \\
(0.31)\end{array}$ & $\begin{array}{l}4.87 \\
(0.17)\end{array}$ & 5.926 & 3 & 0.115 \\
\hline Equitability & $\begin{array}{l}4.70 \\
(0.39)\end{array}$ & $\begin{array}{l}4.83 \\
(0.30) \\
\end{array}$ & $\begin{array}{l}4.68 \\
(0.32)\end{array}$ & $\begin{array}{l}4.77 \\
(0.26)\end{array}$ & 2.368 & 3 & 0.500 \\
\hline Implementation & $\begin{array}{l}4.63 \\
(0.35)\end{array}$ & $\begin{array}{l}4.72 \\
(0.35)\end{array}$ & $\begin{array}{l}4.54 \\
(0.31)\end{array}$ & $\begin{array}{l}4.79 \\
(0.19)\end{array}$ & 3.536 & 3 & 0.316 \\
\hline
\end{tabular}

Note: the difference is significant when $\mathrm{p} \leq 0.05$ 
and regulations (Ali et al., 2017), and application is uniform (Pettinger, 2017) as it is the provincial government that enacts the ordinance fixing the schedule of market values and the procedures of assessment of real properties.

\section{Difference in the level of performance when grouped according to land area}

There is a significant difference in the level of performance of assessment offices when they are grouped according to land area. Smaller land areas revealed a higher level of performance than offices of bigger areas. Offices with bigger land areas are higher-income classed LGUs manned by heads of offices that come from the ranks, while lower-class municipalities are with smaller land areas and are filled by promotion from the provincial office, who have earned the experience, education, training, and acquired competence (Yan \& Ngolob, 2020), professionalism, proper knowledge about the service, and handling of queries of clients (Effiong, 2015).

Table 6. Difference in the Level of Performance according to Land Area

\begin{tabular}{|c|c|c|c|c|c|}
\hline \multirow{2}{*}{ Variable } & \multicolumn{2}{|c|}{ Land Area } & \multirow{2}{*}{ U } & \multirow{2}{*}{ Z } & \multirow[b]{2}{*}{$\mathrm{p}$} \\
\hline & Smaller & Bigger & & & \\
\hline \multirow{2}{*}{ Quality } & 4.57 & 4.50 & 16.000 & -0.323 & 0.747 \\
\hline & $(0.38)$ & $(0.48)$ & & & \\
\hline \multirow{2}{*}{ Efficiency } & 4.60 & 4.62 & 17.500 & -0.081 & 0.935 \\
\hline & $(0.38)$ & $(0.34)$ & & & \\
\hline \multirow{2}{*}{ Timeliness } & 4.37 & 4.32 & 17.500 & -0.080 & 0.936 \\
\hline & $(0.45)$ & $(0.41)$ & & & \\
\hline \multirow{2}{*}{ Performance } & 4.53 & 4.48 & 18.000 & 0.000 & 1.000 \\
\hline & $(0.29)$ & $(0.37)$ & & & \\
\hline
\end{tabular}

Note: the difference is significant when $p \leq 0.05$

\section{Difference in the level of performance when grouped according to income class}

There is no significant difference in the level of performance in terms of quality, efficiency, and timeliness when grouped according to income class. This indicates that the income classification of the municipalities does not influence the performance of assessment offices, that performance is not affected by the internal revenue allocation, but organizational culture (Inuwa, 2016) influences performance.

Table 7. Difference in the Level of Performance according to Income Class

\begin{tabular}{llllllll}
\hline \multirow{2}{*}{ Variable } & \multicolumn{9}{c}{ Income Class } & \multirow{2}{*}{$\chi^{2}$} & \multirow{2}{*}{ df } & $\mathrm{p}$ \\
\cline { 2 - 5 } Q & First & Second & Third & Fourth & & \\
\hline \multirow{2}{*}{ Quality } & 4.60 & 4.67 & 4.10 & 4.60 & 3.769 & 3 & 0.287 \\
& $(0.67)$ & $(0.15)$ & $(0.00)$ & $(0.10)$ & & & \\
\hline \multirow{2}{*}{ Efficiency } & 4.68 & 4.53 & 4.55 & 4.63 & 0.673 & 3 & 0.879 \\
& $(0.47)$ & $(0.31)$ & $(0.64)$ & $(0.06)$ & & & \\
\hline \multirow{2}{*}{ Timeliness } & 4.48 & 3.87 & 4.40 & 4.60 & 5.865 & 3 & 0.118 \\
& $(0.43)$ & $(0.21)$ & $(0.28)$ & $(0.26)$ & & & \\
\hline \multirow{2}{*}{ Performance } & 4.55 & 4.43 & 4.35 & 4.63 & 3.011 & 3 & 0.390 \\
& $(0.51)$ & $(0.15)$ & $(0.35)$ & $(0.12)$ & & & \\
\hline
\end{tabular}

Note: the difference is significant when $p \leq 0.05$

\section{Difference in the level of satisfaction of clients in terms of land area}

There is a significant difference in clients' level of satisfaction in terms of frontline services, service quality, physical setup, and basic facilities when grouped according to land area. Clients from a smaller land area have significantly higher satisfaction than clients from a bigger land area. This finding demonstrates that performance predicts satisfaction. Demands of clients for reevaluation of their commercial and residential properties are common in LGUs with bigger areas; failure to respond affects satisfaction which depends on performance (Khan \& Fasih, 2014; Lee et al., 2016). 
Table 8. Difference in the Level of Satisfaction according to Land Area

\begin{tabular}{|c|c|c|c|c|c|}
\hline \multirow{2}{*}{ Variable } & \multicolumn{2}{|c|}{ Land Area } & \multirow{2}{*}{ U } & \multirow{2}{*}{ z } & \multirow{2}{*}{$p$} \\
\hline & Smaller & Bigger & & & \\
\hline Frontline & 4.68 & 4.52 & $11433.500^{*}$ & -4.237 & 0.000 \\
\hline Services & $(0.50)$ & $(0.45)$ & & & \\
\hline \multirow{2}{*}{ Service Quality } & 4.51 & 4.29 & $9933.500^{*}$ & -5.755 & 0.000 \\
\hline & $(0.62)$ & $(0.41)$ & & & \\
\hline \multirow{2}{*}{ Physical Setup } & 4.57 & 4.40 & $10925.500^{*}$ & -4.710 & 0.000 \\
\hline & $(0.57)$ & $(0.42)$ & & & \\
\hline \multirow{2}{*}{ Basic Facilities } & 4.54 & 4.32 & $10284.000^{*}$ & -5.372 & 0.000 \\
\hline & $(0.60)$ & $(0.45)$ & & & \\
\hline \multirow{2}{*}{ Satisfaction } & 4.58 & 4.39 & $9232.500^{*}$ & -6.417 & 0.000 \\
\hline & $(0.52)$ & $(0.32)$ & & & \\
\hline
\end{tabular}

Note: the difference is significant when $\mathrm{p} \leq 0.05$

\section{Difference in the level of satisfaction according to income class}

There is no significant difference in the level of satisfaction of clients in terms of physical setup. However, there are significant differences in frontline services, service quality, and basic facilities when municipalities are grouped according to income class. Post hoc test revealed that in the overall satisfaction, clients from the 4th income class have significantly higher satisfaction than the clients from the 1st income class, attributed to lesser demand for services in lower-class municipalities, technical expertise, and administrative capacity (De Cesare, 2012).

Table 9. Difference in the Level of Client Satisfaction according to Income Class

\begin{tabular}{|c|c|c|c|c|c|c|c|}
\hline \multirow{2}{*}{ Variable } & \multicolumn{4}{|c|}{ Income Class } & \multirow{2}{*}{$x^{2}$} & \multirow{2}{*}{ df } & \multirow{2}{*}{$P$} \\
\hline & First & Second & Third & Fourth & & & \\
\hline \multirow{2}{*}{$\begin{array}{l}\text { Frontline } \\
\text { Services }\end{array}$} & 4.58 & 4.52 & 4.66 & 4.67 & $12.221^{*}$ & 3 & 0.007 \\
\hline & $(0.42)$ & $(0.51)$ & $(0.67)$ & $(0.39)$ & & & \\
\hline \multirow{2}{*}{ Service Quality } & 4.32 & 4.37 & 4.46 & 4.63 & $26.144^{*}$ & 3 & 0.000 \\
\hline & $(0.45)$ & $(0.52)$ & $(0.77)$ & $(0.45)$ & & & \\
\hline \multirow{2}{*}{ Physical Setup } & 4.44 & 4.51 & 4.49 & 4.56 & 7.326 & 3 & 0.062 \\
\hline & $(0.44)$ & $(0.49)$ & $(0.73)$ & $(0.46)$ & & & \\
\hline \multirow{2}{*}{ Basic Facilities } & 4.34 & 4.44 & 4.54 & 4.54 & $18.491^{*}$ & 3 & 0.000 \\
\hline & $(0.47)$ & $(0.53)$ & $(0.68)$ & $(0.56)$ & & & \\
\hline \multirow{2}{*}{ Satisfaction } & 4.42 & 4.47 & 4.54 & 4.60 & $22.713^{*}$ & 3 & 0.000 \\
\hline & $(0.35)$ & $(0.44)$ & $(0.69)$ & $(0.39)$ & & & \\
\hline
\end{tabular}

Note: the difference is significant when $\mathrm{p} \leq 0.05$

In the area of frontline services, clients from the 3rd and 4th income classes have significantly higher satisfaction than the clients from the 1st and 2 nd income classes, which is explained by the practices of assessors who are not residents of the municipality (Chaoluck, 2016) who demonstrated behaviors that build long term relationships. In the area of service quality, clients from the 4th income class found assessors to be more responsive, hence have significantly higher satisfaction than clients from the 1st and 2nd income classes (Reyes, 2013) who found that responsiveness established a strong relationship with clients.

In the area of basic facilities, clients from the 3rd and 4th income classes have significantly higher satisfaction than the clients from the 1st income class because assessors for lower classed municipalities are exposed to judicious use of resources.

\section{Challenges encountered by assessment offices}

The major challenge encountered by assessment offices is implementing the agrarian reform program, which leads to misclassification in the absence of the final survey (Zaragoza \& Caelian, 2020). 
Administrative challenges (Norregaard, 2013) include budget constraints, lack of mobility, and weak enforcement (Kalkuhl et al., 2018), demanding a sound policy on assessment.

Moreover, political challenges (Kim et al., 2020) relate to the delay of some local authorities to update the schedule of market value and setting of the assessment levels, which is a legislative function (De Cesare, 2012) as political influence in the valuation process.

Furthermore, a set of challenges concerns policies such as limitations in the schedule of market value, undervaluation (Small et al., 2016), actual use as the basis of assessment, low assessment ratios (Bauerly, 2016), the accurate basis of market values, the appropriate basis of classification of property, and basis of exemptions.

Table 10. Challenges encountered by assessment offices

\begin{tabular}{|c|c|c|c|}
\hline \multicolumn{2}{|r|}{ Challenges } & \multirow{2}{*}{$\frac{f}{25}$} & \multirow{2}{*}{$\begin{array}{c}\% \\
15.06\end{array}$} \\
\hline 1. & $\begin{array}{l}\text { The implementation of the agrarian reform } \\
\text { program. }\end{array}$ & & \\
\hline 2. & Budget constraints. & 19 & 11.45 \\
\hline 3. & Lack of mobility & 14 & 8.43 \\
\hline 4. & Weak enforcement. & 13 & 7.83 \\
\hline 5. & $\begin{array}{l}\text { Refusal of some local authorities to update the } \\
\text { schedule of market value. }\end{array}$ & 12 & 7.23 \\
\hline 6. & $\begin{array}{l}\text { Policy issues such as limitations in the schedule of } \\
\text { market value. }\end{array}$ & 11 & 6.63 \\
\hline 7. & Undervaluation & 11 & 6.63 \\
\hline 8. & Decentralized method of rendering services. & 10 & 6.02 \\
\hline 9. & $\begin{array}{l}\text { There is political interference in the setting of } \\
\text { market values. }\end{array}$ & 10 & 6.02 \\
\hline 10. & $\begin{array}{l}\text { Actual use is the basis of assessment instead of the } \\
\text { highest and best use. }\end{array}$ & 9 & 5.42 \\
\hline 11. & Low assessment ratios and assessment levels. & 8 & 4.82 \\
\hline 12. & Market values are not based on market evidence. & 7 & 4.22 \\
\hline 13. & $\begin{array}{l}\text { Classification of property is not based on the } \\
\text { zoning ordinance. }\end{array}$ & 7 & 4.22 \\
\hline 14. & There are many properties subject to exemptions. & 6 & 3.61 \\
\hline 15. & $\begin{array}{l}\text { Others: Unfavorable effect of collective CLOA; } \\
\text { outdated CLUP; Zoning ordinance is not used; } \\
\text { transfer the approval of SMV to DOF. }\end{array}$ & 4 & 2.41 \\
\hline
\end{tabular}

Overall, the very great extent of implementation of assessment principles validated the theory of new public management, demonstrating assessment services as more results-oriented and emphasizing empowerment and satisfaction of clients through public service. Also, the theory of total quality management was validated because the findings revealed that operations and processes were managed, and outstanding performances were demonstrated. Further, the dimensions of the Servqual Model used as a guide in measuring satisfaction were able to identify gaps in the performance of assessment offices.

\subsection{Conclusion}

The very great extent of implementation of assessment principles implies outstanding performance translated into very satisfied taxpayers implying that the credibility of assessment principles facilitated the accurate implementation of real property taxation, hence the need for local governments to sustain operations of local assessment offices.

The significant differences revealed in the level of satisfaction of taxpayers deserve the attention of higher offices such as the Bureau of Local Government Finance (BLGF) on the review of assessment policies on the approval of the schedule of market value, the importance of the land use plan and the zoning ordinance, and the unfavorable effect of the collective certificate of land ownership award by the Department of Agrarian Reform (DAR). 
Further, the need for training and higher education to ensure the competence of assessors is found to be a necessity.

\section{REFERENCES}

Alegata, W. C. G., \& Caelian, M. V. (2019). The implementation of the anti-red tape act and client satisfaction of state universities and colleges in Negros Occidental. Philippine Social Science Journal, 2(1), 118-118. https:// doi.org/10.52006/main.v2i1.69

Ali, M., Fjeldstad, O. H., \& Katera, L. (2017). Property taxation in developing countries. CMI Brief. http://hdl.handle. net/11250/2475412

Ariani, D. W. (2015). Employee satisfaction and service quality: Is there relations? https://www.cscjournals.org/ manuscript/Journals/IJBRM/Volume6/Issue3/IJBRM-187.pdf

Bauerly, C. (2016). 2016 Property values and assessment practices report assessment year 2015. https://www.leg. mn.gov/docs/2016/mandated/160287.pdf

Benedicto, H. R., \& Caelian, M. V. (2021). The influence of work ethics on job performance of government employees. Philippine Social Science Journal, 4(1), 71-82. https://doi.org/10.52006/main.v4i1.313

Chaoluck, P. (2016). Assessment of customer perceptions towards frontline service employees' role behaviors. https://digital.library.adelaide.edu.au/ dspace/bitstream/2440/107456/2/02whole.pdf

Cheymetova, V. A., \& Scherbakov, V. V. (2017). Methodological approaches to managerial efficiency evaluation of organization. Espacios, Venezuela, 38(48).

De Cesare, C. M. (2012). Improving the performance of the property tax in Latin America. Cambridge, MA: Lincoln Institute of Land Policy. https://www.lincolninst.edu/sites/default/files/pubfiles/improving-performanceproperty-tax-latin-america-full_0.pdf.

Dimopoulos, T. (2015). Overview of property taxation systems. http://hephaestus.nup.ac.cy/bitstream/ handle/11728/7097/Overview-of property.pdf?sequence=1\&isAllowed=y

Duca, J. V., Muellbauer, J., \& Murphy, A. (2010). Housing Markets and the Financial Crisis of 2007-2009: Lessons for the future. Journal of Financial Stability. https://doi.org/10.1016/j.jfs.2010.05.002

Effiong, J. B. (2015). A comparative study of valuation variance and accuracy between Nigeria and the UK. International Letters of Social and Humanistic Sciences, 57, 94-105. https://doi.org/10.18052/www.scipress. com/ilshs. 57.94

Felis, P. (2014). Theoretical concepts of property tax, an essential source of local government revenue in Europe. Management Theory and Studies for Rural Business and Infrastructure Development, 36(4), 802-809. http:// dx.doi.org/10.15544/mts.2014.075

Gayer, C., \& Mourre, G. (2012). Property taxation and enhanced tax administration in challenging times. Economic Papers, 463.

Goodfellow, T. (2016). Property taxation and economic development: Lessons from Rwanda and Ethiopia. SPERI Global Political Economy Brief No. 4: Sheffield Political Economy Research Institute. https://www.eldis.org/ document/A102325

Gomez, M. (2010). Towards Tax Justice. Policy Research Paper. Tax Justice Network. https://www.aer.ph/taxjustice/ wp-content/pdf/Real_Property.pdf

Inuwa, M. (2016). Job satisfaction and employee performance: An empirical approach. The Millennium University Journal, 1(1), 90-103. http://www.themillenniumuniversity.edu.bd/journal/index.php/TMUJ/article/view/10

Kadiresan, V., Selamat, M. H., Selladurai, S., Ramendran, C. S., \& Mohamed, R. K. M. H. (2015). Performance appraisal and training and development of human resource management practices (HRM) on organizational commitment and turnover intention. Asian Social Science, 11(24), 162.

Kalkuhl, M., Milan, B. F., Schwerhoff, G., Jakob, M., Hahnen, M., \& Creutzig, F. (2018). Can land taxes foster sustainable development? An assessment of fiscal, distributional and implementation issues. Land Use Policy, 78, 338-352. https://doi.org/10.1016/j.landusepol.2018.07.008

Khalfan, I., Said, S., Jamaluddin, Z., Widyarto, S. (2020). Framework on quality management practices and operational performance for ISO 9001 certified construction industries. International Journal of Academic Research in Accounting, Finance and Management Sciences. http://dx.doi.org/10.6007/IJARAFMS/v10-i2/7437

Khan, M. M., \& Fasih, M. (2014). Impact of service quality on customer satisfaction and customer loyalty: Evidence from banking sector. Pakistan Journal of Commerce and Social Sciences 2014, Vol. 8 (2), 331-354. http://hdl. handle.net/10419/188141

Kim, S., Chung, I. H., \& Eom, T. H. (2020). Institutional differences and local government performance: evidence from property tax assessment quality. Public Performance \& Management Review, 43(2), 388-413. https:// doi.org/10.1080/15309576.2019.1627223

Kucharska-Stasiak, E. (2013). Uncertainty of property valuation as a subject of academic research. Real Estate Management and Valuation, 21(4), 17-25. https://www.researchgate.net/profile/Ewa-Kucharska-Stasiak/ publication/270266774_UNCERTAINTY_OF_PROPERTY_VALUATION_AS_A_SUBJECT_OF_ACADEMIC RESEARCH/links/56fba81308aef6d10d9̄18b̄27/UNCERTAINTY-OF-PROPERTY-VALUATTION-AS-A-SUBJECTOF-ACADEMIC-RESEARCH.pdf

Kuei, C. H., \& Madu, C. N. (1995). Managers' perceptions of factors associated with quality dimensions for the different types of firms. Quality Management Journal, 2(3), 67-80. https://doi.org/10.1080/10686967. 1995.11918692 
Kumar, R. (2014). Research Methodology: A Step-by-Step Guide for Beginners. London: SAGE Publications. https:// books.google.com.ph/books? $h \mathrm{hl}=$ en\&lr $=$ \&id $=J 2 J 7 D w A A Q B A J \& o i=f n d \& p g=P P 1 \& d q=K u m a r,+R .+(201$ 4).+Research+Methodology:+A+Step-by-Step+Guide+for+Beginners.+London:+SAGE+Publications.\& ots $=$ cvokBzMEnn\&sig=mI_2XIcP9D68IILBogxbXiXHfMg\&redir_esc $=y \# v=$ onepage \&q\&f=false

Laguyo, J. P., \& Caelian, M. V. (2020). Police operational competence and performance of graduates of a regional training center. Philippine Social Science Journal, 3(2), 157-158. https://doi.org/10.52006/main.v3i2.177

Lee, Y. C., Wang, Y. C., Lu, S. C., Hsieh, Y. F., Chien, C. H., Tsai, S. B., \& Dong, W. (2016). An empirical research on customer satisfaction study: a consideration of different levels of performance. Springer Plus, 5(1), 1-9. https://doi.org/10.1186/s40064-016-3208-z

Lu, M.H. (2001), "Handbook of Total Quality Management," International Journal of Quality \& Reliability Management, Vol. 18 No. 1, pp. 104-107. https://doi.org/10.1108/ijqrm.2001.18.1.104.2

Monkam, N., \& Moore, M. (2015). How property tax would benefit Africa. London: Africa Research Institute.

Morrissey, O. (2013). Tax incidence in low-income countries. EPS-PEAKS (Economics and Private Sector Professional Evidence and Applied Knowledge Services), 19-20.

Mustafa, A. S., \& Okeyo, W. (2018). Relationship between employee performance and customer service quality in Kenya bureau of standards.

Norregard, M. J. (2013). Taxing immovable property revenue potential and implementation challenges. International Monetary Fund.

Oxborne, D., \& Gaebler, T. (1992). Reinventing government. Journal of Leisure Research, 27(3), 302. https://doi.org/ 10.1080/00222216.1995.11949751

Pakurár, M., Haddad, H., Nagy, J., Popp, J., \& Oláh, J. (2019). The service quality dimensions that affect customer satisfaction in the Jordanian banking sector. Sustainability, 11(4), 1113. https://doi.org/10.3390/su11041113

Perez, M. G., \& Ilagan, L. S. (2020). Clients' satisfaction on the frontline services of a government higher education institution. European Journal of Education Studies. http://dx.doi.org/10.46827/ejes.v0i0.2801

Pettinger, T. (2017). Cracking economics. Cassell. https://www.goodreads.com/en/book/show/36369222-crackingeconomics

Plimmer, F., \& McCluskey, W. J. (2016). Property taxation for developing economies. Copenhagen: The International Federation of Surveyors (FIG). https://www.fig.net/resources/publications/figpub/pub67/Figpub67.pdf

Pinyochatchinda, S. \& Walsh, J. (2015). The role of SEZs in Thailand's regional economic development. https:// cberuk.com/cdn/conference_proceedings/2015iacp32.pdf

Pukīte, I., \& Geipele, S. (2017). Determining customer satisfaction in the real estate management sector in Riga. Baltic Journal of Real Estate Economics and Construction Management, 5(1), 226-237. https://doi. org/10.1515/bjreecm-2017-0017

Reyes, J. C. (2013). Measures of service quality between local government units of Angeles and San Fernando in the Province of Pampanga, Philippines: Its implications to constituents' satisfaction.

Ritchie, J., Lewis, J., Nicholls, C. M., \& Ormston, R. (Eds.). (2013). Qualitative research practice: A guide for social science students and researchers. Sage. file:///C:/Users/User/AppData/Local/Temp/1476270470-pdf.pdf

Roberto, J., \& Madrigal, D. (2018). Teacher quality in the light of the Philippine Professional Standards for Teachers. Philippine Social Science Journal, 1(1), 67-80. https://doi.org/10.52006/main.v1i1.13

Sadikoglu, E., \& Olcay, H. (2014). The effects of total quality management practices on performance and the reasons of and the barriers to TQM practices in Turkey. Advances in Decision Sciences. https://doi. org/10.1155/2014/537605

Singh, K. (2016). Influence of internal service quality on job performance: A case study of the royal police department. Procedia-Social and Behavioral Sciences, 224, 28-34. https://doi.org/10.1016/j. sbspro.2016.05.396

Slack, E., \& Bird, R. M. (2015). How to reform the property tax: Lessons from around the world. Institute on Municipal Finance and Governance. https://munkschool.utoronto.ca/imfg/uploads/325/1689_imfg_no.21_ online_final.pdf

Small, G., Vail, M., \& Akbar, D. (2016). Property values and regional economic vitality: Valuation methods as an indicator of property market behavior. Australasian Journal of Regional Studies, The, 22(2), 285-306. https:// search.informit.org/doi/10.3316/ielapa.328479094536405

Soutar, G. N. (2001). Service quality, customer satisfaction, and value: An examination of their relationships. Service Quality Management in Hospitality, Tourism, and Leisure, 97-110.

Stoker, G. (2018). Governance as theory: Five propositions. International Social Science Journal, 68(227-228), 15-24. https://doi.org/10.1111/issj.12189

Tumbagahan, J.S. (2018). Real Property Tax Valuations in the $3^{\text {rd }}$ and $4^{\text {th }}$ Congressional Districts of Negros Occidental. Unpublished Masters Study. Recoletos de Bacolod Graduate School, University of Negros Occidental-Recoletos.

Villaroman, L. (2017). Factors affecting collection of real property tax in the provincial treasurer's office of Nueva Ecija. Available at SSRN 3093130. http://dx.doi.org/10.2139/ssrn.3093130

Yan, L., \& A. Ngolob, R. (2020, July). Customer satisfaction of real estate clients in China. In 2020 The 11th International Conference on E-business, Management, and Economics (pp. 53-58). https://doi. org/10.1145/3414752.3414764 
Yang, A. J. F., Huang, Y. C., \& Chen, Y. J. (2019). The importance of customer participation for high-contact services: Evidence from a real estate agency. Total Quality Management \& Business Excellence, 30(7-8), 831-847. https://doi.org/10.1080/14783363.2017.1341814

Zaragoza, S. M., \& Caelian, M. V. (2020). Fiscal implication of agrarian reform program to the real property tax collection in Negros Occidental. Philippine Social Science Journal, 3(3), 85-94. https://doi.org/10.52006/main. v3i3.263

\section{Correspondence:}

JENNIFER S. TUMBAGAHAN*

jennytumbagahan1117@gmail.com

0000-0002-5697-8441

MERLITA V. CAELIAN

merlita_caelian@yahoo.com

https://orcid.org/0000-0002-4671-4047

ZEAPHARD GERHART V. CAELIAN

zgvc17@gmail.com

https://orcid.org/0000-0003-0155-8826

*Principal Correspondent 